УДК [904.22: 904.5] (477.75) «638»

DOI: https://doi.org/10.33782/eminak2021.2(34).514

\title{
ЗБРОЯ У ПОХОВАЛЬНОМУ ОБРЯДІ УСТЬ-АЛЬМІНСЬКОГО НЕКРОПОЛЯ (ПІВДЕННО-ЗАХІДНИЙ КРИМ)
}

\author{
Геннадій Медведєв \\ Інститут археології Криму (Сімферополь, Автономна Республіка Крим) \\ e-mail: medvedgen@gmail.com \\ ORCID: https://orcid.org/0000-0003-0977-8321
}

У статті розглядаються поховання зі зброєю з Усть-Альмінського некрополя, його типологія, хронологія та статистика, а також місце та роль зброї у поховальному обряді. За кількістю озброєння Усть-Альмінський некрополь виділяється серед пізньоскіфських пам'яток Криму.

Основна роль зброї у поховальному обряді - його функціональне призначення. Аналіз поховальних комплексів Усть-Альмінського некрополя показав, що за кількістю зброї у похованнях, на першому місці була клинкова зброя. Потім зброя дистанційного бою (луки і стріли), і на третьому місці - списи, а ще далі - сокири. У результаті порівняльного аналізу поховального обряду Усть-Альмінського некрополя, ми знаходимо подібні риси в обрядах сарматів у Поволжі, на Дону, Прикубанні, Прикавказзі та Боспорі.

Ключові слова: пізньоскіфська культура, поховання зі зброєю, сармати, мечі та кинджали, дистанційна зброя, списи, сокири

Питання пов'язані 3 вивченням ролі зброї у поховальному обряді пізньоскіфської та сарматської культур, протягом років і на даний час залишаються актуальними. Зброя є значущим джерелом у реконструкції етнічних, культурних, військово-політичних та інших подій і контактів у перші століття нашої ери в Криму та за його межами. Знахідки зброї походять в основному з поховальних комплексів, тому залишається високою значимість досліджень поховальних споруд.

Усть-Альмінський некрополь розташований в 1,2 км на північний захід від с. Піщане (кол. Алма-Тамак) Бахчисарайського району, що у Південно-Західному Криму, на схід від городища (рис. 1).

На Усть-Альмінському некрополі протягом багатьох сезонів було досліджено значну кількість поховальних споруд зі зброєю та накопичений значний археологічний матеріал - поховальні комплекси кінця II ст. до н.е. - середини III ст. н.е. (рис. 2).

Велика частина поховальних комплексів Усть-Альмінського некрополя, в яких містилася зброя, були опубліковані у низці робіт ${ }^{1}$. А у недавній час вийшли друком,

\footnotetext{
1 Высотская Т.Н. Усть-Альминское городище и некрополь. Киев: Киевская Академия Евробизнеса, 1994. Табл. 2, 21; 10, 28; 27, 42; 29, 24; 31, 33; 38, 21; 39: 13; 40,15; 43, 34; 44, 9, 39; Пуздровский А.Е. Крымская Скифия II в. до н.э. - III в. н.э. Погребальные памятники. Симферополь: Бизнес-Информ, 2007. Рис. 86-90; 92-94; Склеп с элитными воинскими погребениями из Усть-Альминского некрополя // История и археология Крыма. Вып. II. 2015. С. 186-199; Пуздровский А.Е., Медведев Г.В. Погребения I-II вв. н.э. из Усть-Альминского некрополя // Херсонесский сборник. Вып. XIV. 2005. Рис. 4, 1; Пуздровский А.Е., Труфанов А.А. Погребение воина из Усть-Альминского некрополя (могила 848) // История и археология Крыма. Вип. IV. 2016. С. 27-37; Полевые исследования УстьАльминского некрополя в 2008-2014 гг. // Усть-Альминское городище и некрополь в ЮгоЗападном Крыму. Т. 1. Симферополь: Бровко А.А., 2016. Рис. 5; 7, 7; 17,10; 70; 135, 8; 138, 16, 20 ; 157; 158; 163; Полевые исследования Усть-Альминского некрополя в 2004-2007 гг. // УстьАльминское городище и некрополь в Юго-Западном Крыму. Т. 2. Симферополь: Бровко А.А. 2017.
} 
статті присвячені наконечникам списів, клинкової (мечів і кинджалів) і зброї дистанційного бою (луки, стріли та сагайдачні набори) з Усть-Альмінського некрополя². Але спеціальної узагальнюючої роботи з аналізом даних, присвяченої зброї та іiї місцю й ролі у поховальному обряді Усть-Альмінського некрополя до теперішнього часу не існує.

Всього, як відомо, на Усть-Альмінському некрополі проаналізовано близько 171 поховання зі 187 одиницями зброї.

Клинкова зброя - найчисленніша серед усіх видів зброї на даному некрополі, де виявлено 110 мечів і кинджалів (58,8\%). Клинки були представлені трьома основними типами, з них у фрагментах невизначених типів було близько 24-х клинків. Найбільша кількість містилася у склепах $(63,3 \%)^{3}$.

Мечі та кинджали з кільцевим навершям і прямим перехрестям відрізняються між собою незначно, за типологією А.М. Хазанова або О.В. Симоненка ці відмінності виражені у формі клинка 4 .

На Усть-Альмінському некрополі відомий 31 екземпляр мечів і кинджалів 3 кільцевим навершям, що склало майже третину $(28,1 \%)$ від загальної кількості клинкової зброї. У некрополі виділяється один екземпляр без перехрестя. Клинки такого типу, без перехрестя, досить рідко зустрічалися у похованнях сарматів 5 .

У Криму клинки з кільцевим навершям досить добре відомі у похованнях пізніх скіфів і сарматів. I такі мечі та кинджали було знайдено у некрополях Неаполя Скіфського, Бітака, Бельбек IV, Завітне, Нейзац, Опушки, Беляус6.

Рис. 10; 40; 42, 1, 2, 10; 46, 1, 15; 49, 1; 70, 3; 84, 12, 14; 89; 105, 6; 110; 128, 6; 150; 158, 7, 8, 10; 160, $4 ; 170,5,6,15 ; 196,15 ; 203,9$; Полевые исследования Усть-Альминского некрополя в 20002003 гг. // Усть-Альминское городище и некрополь в Юго-Западном Крыму. Т. 3. Симферополь: Бровко А.А., 2017. Рис. 3, 2; 11; 15; 34, 27; 35, 11; 92; 99, 1; 118; 136, 2; 138; 150, 10, 11; 167, 1; 180, 6; Труфанов А.А., Мордвинцева В.И. Воинское погребение середины І в. н.э. из Усть-Альминского некрополя (Юго-Западный Крым) // Проблемы истории, филологии, культуры. 2016. Вып. 2. Pис. 1; 4; Mordvintseva V.N. Decorated swords as emblems of power on the steppes of the northern Black Sea region (3rd C. BC. $-3^{\text {rd }}$ C. AD) // Anabasis. Studia Ciassica et Orientalia. 2016. Vol. 6. (2015). Fig. 8: 3, 4; Труфанов А.А., Масякин В.В. Римский меч из Усть-Альминского некрополя (ЮгоЗападный Крым) // Stratum plus. 2019. Вып. 4. Рис. 3; Медведев Г.В. Могилы с коллективными погребениями из Усть-Альминского некрополя // Археологический альманах. 2010. Вып. 22. Рис. 11, 18; Медведев Г.В. Три погребения первых веков нашей эры с мечами из Усть-Альминского некрополя // История и археология Крыма. 2019. Вып. IX. С. 100-113; Медведєв Г.В. Мечі та кинджали у поховальному обряді Усть-Альмінського некрополя // Археологія і давня історія України. 2020. Вип. 3 (36). С. 266-280.

2 Труфанов А.А. Наконечники копий из Усть-Альминского некрополя // История и археология Крыма. 2016. Вып. IV. С. 47-68; Медведев Г.В. Оружие дистанционного боя (луки и стрелы) в погребальном обряде Усть-Альминского некрополя (Юго-Западный некрополь) (у друці).

3 Медведєв Г.В. Мечі та кинджали у поховальному обряді Усть-Альмінського некрополя... С. 266.

${ }_{4}$ Хазанов А.М. Очерки военного дела сарматов... С. 5-6; Симоненко А.В. Сарматские всадники Северного Причерноморья. Санкт-Петербург: Санкт-Петербургский государственный университет, 2010. С. 32, 36, 38.

5 Хазанов А.М. Очерки военного дела сарматов... Табл. IV, 3; V, 3; Глебов В.П., Парусимов И.Н. Новые сарматские погребения в бассейне р. Сал (о соотношении раннесарматской и среднесарматской культур) // Сарматы и их соседи на Дону: Материалы и исследования по археологии Дона / Отв. ред. Ю.К. Гугуев. 2000. Вып. III. С. 66, Рис. 7; Кривошеев М.В. Вооружение позднесарматского времени нижнего Поволжья // Доклады к VI Международной конференции «Проблемы сарматской археологии и истории». Вооружение сарматов: региональная типология и хронология / Отв. ред. Л.Т. Яблонский, А.Д. Таиров. Челябинск, 2007. Рис. 1, 1.

6 Бабенчиков В.П. Новый участок некрополя Неаполя Скифского // Вестник древней истории. 1949. Вып. 1. С. 116-118, Рис. 7б; Пуздровский А.Е. Погребения Битакского могильника первых веков н. э. с оружием и конской уздой // Поздние скифы Крыма: Труды государственного исто- 
На території поширення сарматських пам'яток, раніше за даними дослідників, було відомо близько 500 клинків з кільцевим навершям. А найбільша їх концентрація відбувалася «між Нижнім Дунаєм, басейном р.Урал і Північним Кавказом»7. У степовій зоні Північного Причорномор'я та лісостепу враховано 74 клинки 8 .

Мечі та кинджали з перехрестям і без навершя, за типологією належать до типу 1 мечів з рукояткою-штирем9. На Усть-Альмінському некрополі таких клинків виявлено незначну кількість - близько 10 екземплярів ${ }^{10}$.

У Криму клинків з перехрестям і без навершя було відомо небагато. Один такий меч, наприклад, був знайдений у некрополі Неаполя Скіфського. У недавній час, такі клинки були зафіксовані у могильнику біля с. Завітне в двох похованнях I ст. н.е.11

Знахідки мечів з рукояткою-штирем і перехрестям, особливо біметалевих, на сарматських територіях досить рідкісні та відомі у сарматських похованнях Нижнього Поволжя і Прикубання ${ }^{12}$. Мечі з ромбоподібним перехрестям могли походити з Ханьських зразків і могли бути завезеними з Китаю разом з іншими категоріями імпорту ${ }^{13}$.

рического музея. 2001. Вып. 118. С. 137, Рис. 10; Крымская Скифия. II в. до н.э. - II в. н.э.... Рис. 25, I; Гущина И.И., Журавлев Д.В. Некрополь римского времени Бельбек IV в Юго-Западном Крыму // Труды ГИМ. 2016. Вып. 205. Т. 1. С. 73; Гущина И.И., Журавлев Д.В. Некрополь римского времени Бельбек IV в Юго-Западном Крыму // Труды ГИм. 2016. Вып. 205. Т. 2. Табл. 242, 1, 4; Гущина И.И. О сарматах в Юго-Западном Крыму // Советская археология. 1967. Вып. 1. С. 47, Рис. 3, 6; Богданова Н.А. Могильник первых веков нашей эры у с. Заветное // Археологические исследования на юге восточной Европы: Труды ГИМ. 1989. Вып. 70 (II). С. 57, 59, Табл. XXII, 1, 2; Храпунов И.Н. Погребение воина 2 в. н.э. из могильника Опушки // Древняя Таврика / Отв. ред. Ю.П. Зайцев, В.И. Мордвинцева. Симферополь: Универсум, 2007. С. 116, Рис. 4: 6; Оружие из могильника Нейзац // Terra Barbarica. Monumenta archeological Barbarica. Series Gemina. 2010. Vol. II. C. 535, Рис. 1; Волошинов А.А., Масякин В.В. Погребения с оружием из некрополя римского времени у с. Заветное в Юго-Западном Крыму (раскопки 2005-2006 гг.) // Древняя Таврика / Отв. ред. Ю.П. Зайцев, В.И. Мордвинцева. Симферополь: Универсум, 2007. С. 292, Рис. 3, 11; 6, 2; Дашевская О.Д. Поздние скифы в Крыму. Свод археологических источников, Д 1-7. Москва: Наука, 1991. Табл. 61, 2, 4, 5, 7; Некрополь Беляуса. Симферополь: Феникс, 2014. Табл. 71, 2.

7 Sadowski S. Miecz z grobu 8 cmientarzyska Zvenihorod - «Hoeva Hora» na Ukraine. Przyczynek do badań nad rozprzestrzenieniem się mieczy z pierścieniowatym zakończeniem rękojeści // Sarmaci i germanie / Eds. A. Kokowski. Lublin: Wydawnictwo Uniwersytetu Marii Curie-Skłodowskiej, 2004. S. 265-288; Садовски С. Мечи и кинжалы с кольцевым навершием // Боспорские чтения. Боспор Кимерийский и варварский мир в период античности и средневековья. Oikoc / Отв. ред. В.Н. Зинько. Керчь, 2006. С. 254-255; Храпунов И.Н. Погребение воина 2 в. н. э. из могильника Опушки... С. 116; Оружие из могильника Нейзац... С. 535; Медведев Г.В. Три погребения первых веков нашей эры с мечами из Усть-Альминского некрополя // История и археология Крыма. 2019. Вып. ІХ. С. 103; Храпунов И.Н., Эстер И., Кульчар В., Стоянова А.А. Оружие сарматского времени в Крыму и в Альфельде // Материалы по археологии, истории и этнографии Таврии. 2020. Вып. XXV. C. 7.

8 Симоненко А.В. Сарматские всадники Северного Причерноморья... С. 32.

9 Хазанов А.М. Очерки военного дела сарматов... С. 17; Симоненко А.В. Сарматские всадники Северного Причерноморья... С. 43.

10 Медведєв Г.В. Мечі та кинджали у поховальному обряді Усть-Альмінського некрополя... С. 270271 , рис. 4, табл. 3.

11 Волошинов А.А., Масякин В.В. Погребения с оружием из некрополя римского времени у с. Заветное в Юго-Западном Крыму (раскопки 2005-2006 гг.) ... С. 294, рис. 8, 8.

12 Марченко И.И. Сираки Кубани. Краснодар: Краснодарский государственный университет, 1996. С. 56; Лимберис Н.Ю., Марченко И.И. Погребение сарматского воина на некрополе меотского городища // Евразия в скифо-сарматское время. Труды государственного исторического музея. 2012. Вып. 191. С. 276, рис. 4, 1.

13 Puzdrovskij A.E., Zajcev J.P. Prunkbestattungen des I Jh. n. C. in der Nekropole Ust-Al'ma auf der Krim. 
Мечі та кинджали без металевого навершя і перехрестя. Основними характеристиками цього типу мечів є рукоять, викувана разом 3 клинком у вигляді штиря, або бруска без металевого навершя. У таких мечів навершя могло бути з кістки, алебастру або халцедону14.

Мечі і кинджали без навершя та перехрестя відносять до 2 і 3 типів за класифікацією А.М. Хазанова. Клинки відрізняються переходом від ручки до клинка, під тупим кутом або прямим кутом 15 . Зброї даного типу на Усть-Альмінському некрополі знайдено 45 екземплярів. Один з найбільш ранніх екземплярів відноситься до середини I ст. н.е. ${ }^{16}$ На думку дослідників, даний тип клинка широко використовувався на території Середньої Азії та Близького Сходу, хоча зустрічаються іноді й у Данії та Північній Німеччини у кінці II - початку III ст. н.е. ${ }^{17}$

Ранні знахідки таких мечів у пізньоскіфських некрополях відомі рідко. Один меч походить з мавзолею Неаполя Скіфського та поодинокі екземпляри з некрополів Беляус і Кольчугіно ${ }^{18}$. Значна кількість мечів і кинджалів без перехрестя, що були виявлені у Криму, походить з некрополів Неаполя Скіфського, Бітака, Завітне, Бельбек IV, Скалисте III, Беляус ${ }^{19}$.

Мечі та кинджали без перехрестя та металевого навершя досить добре представлені у сарматських некрополях Поволжя, Дону та Прикубання 20 . Наприклад, на Дону довгі мечі без перехрестя з'явилися у II-I ст. до н.е. і в незначній кількості як імпорт із Середньої Азї̈21. Ці клинки набули поширення у Північному Причорно-

Die Ausgrabungen des Jahres 1999 // Eurasia antiqua. 2004. Vol.10. Abb. 6; Волошинов А.А., Масякин В.В. Погребения с оружием из некрополя римского времени у с. Заветное в Юго-Западном Крыму (раскопки 2005-2006 гг.)... С. 294; Симоненко А.В. Периодизация военного дела номадов Евразии в эпоху раннего железа / Отв. ред. Лукьяшко С.И. (Война и военное дело в скифосарматском мире. Материалы международной научной конференции памяти А.И. Мелюковой. Ростов-на-Дону: ЮНЦ РАН, 2014. С. 337.

${ }_{14}^{14}$ Симоненко А.В. Сарматские всадники Северного Причерноморья... С. 46, рис. 29; 30; 32; Безуглов С.И. Позднесарматские мечи (по материалам Подонья) // Сарматы и их соседи на Дону: Материалы и исследования по археологии Дона. 2000. Вып. 1. С. 170, 172.

15 Симоненко А.В. Сарматские всадники Северного Причерноморья... С. 46, 57, 58.

16 Медведєв Г.В. Мечі та кинджали у поховальному обряді Усть-Альмінського некрополя... С. 272, Рис. 5, табл. 4.

17 Безуглов С.И. Степь и Танаис во II-III вв. н.э. // Крым в сарматскую эпоху (II в. до н.э. - IV в. н.э.). Материалы X Международной научной конференции «Проблемы сарматской археологии и истории» / Отв. ред. И.Н. Храпунов. 2019. Вып. V. С. 50.

18 Дашевская О.Д. Поздние скифы в Крыму. Свод археологических источников. Вып. Д 1-7. Москва: Наука, 1991. табл. 61, 10; Некрополь Беляуса. Симферополь: Феникс, 2014. С. 30, табл. 62, 1; Храпунов И.Н., Масякин В.В., Мульд С.А. Позднескифский могильник у с. Кольчугино // Бахчисарайский историко-археологический сборник. 1997. Вып. 1. С. 97, Рис. $19,3$.

${ }^{19}$ Сымонович Э.А. Население столицы позднескифского царства (по материалам Восточного некрополя Неаполя скифского). Киев: Наукова думка, 1983. С. 73, табл. XIV, 6; Пуздровский A.E. Погребения Битакского могильника первых веков н.э. с оружием и конской уздой... С. 125, 129, 130, Рис. 3, 2; 5, 3; 7, 10; Крымская Скифия II в. до н.э. - III в. н.э. Погребальные памятники... Рис. 13, 2; 25, 2; Гущина И.И. О сарматах в Юго-Западном Крыму // Советская археология. 1967. Вып. 1. С. 47, Рис. 4, 1; Богданова Н.А. Могильник первых веков нашей эры у с. Заветное... С. 59, Табл. XXII: 3, 4; Гущина И.И., Журавлев Д.В. Некрополь римского времени Бельбек IV в Юго-Западном Крыму... Т. 1. С. 74; Т. 2. Табл. 242, 3, 5-7; Богданова Н.А., Гущина И.И., Лобода И.И. Могильник Скалистое III в Юго-Западном Крыму (I-ІІІ вв. н.э.) // Советская археология. 1974. Вып. 4. С. 146, Рис. 8, 52; Дашевская О.Д. Поздние скифы в Крыму... Табл. 61, 8-17.

20 Хазанов А.М. Очерки военного дела сарматов... С. 17, Табл. X, 1-3, 5, XI, 1, 2, 4-7; XIII, 1-2; Марченко И.И. Сираки Кубани... С. 56-58, рис. 78, 9; 97, 12; Кривошеев М.В. Вооружение позднесарматского времени Нижнего Поволжья... Рис. 1, 2-8.

21 Безуглов С.И. Позднесарматские мечи (по материалам Подонья) // Материалы и исследования 
мор'ї та Криму в I - на початку II ст. н.е.22 Мечі без металевого навершя та перехрестя стають популярним типом на пам'ятках сарматського часу з другої половини II ст. H.e. ${ }^{23}$

Клинків інших типів знайдено два екземпляра. Це кинджал з прямим перехрестям і «ріжкоподібним» навершям - його фрагменти (40см) були знайдені у пограбованому склепі 315 разом з уламками ще трьох мечів ${ }^{24}$. Він міг бути пізнім варіантом клинка з «серпоподібним» навершям 25 .

Фрагменти меча римського типу та бронзові деталі піхов походять 3 пограбованого склепу 1120, який датований серединою I ст. н.е. - серединою II ст. н.е. Аналогічні мечі відомі в Криму та на території Німеччини ${ }^{26 .}$

Більшість поховань $з$ клинками з Усть-Альмінського некрополя датуються серединою - другою половиною I - початком II ст. н.е. ${ }^{27}$

Меч розташовувався у похованні традиційно з правого боку, за винятком окремих випадків, коли клинок був з лівого боку, або в іншому положенні. Наприклад, коли меч був між ніг (рис. 3, IV), (с. 520/26) - поверх кістяка, або (с. 750), біля правого плеча вістрям до черепу ${ }^{28}$.

У поховальному обряді Усть-Альмінського некрополя клинкова зброя відіграє провідну роль (59,7\%). Мечі без перехрестя та навершя - нечисленні $(40,9 \%)$. Майже третину - мечі з кільцевим навершям $(28,1 \%)$. Найрідше - клинки 3 перехрестям $(9,0 \%)^{29}$.

Після клинкової, зброя дистанційного бою (луки та стріли) найбільш масово представлена у похованнях даного некрополя.

Всього на Усть-Альмінському некрополі проаналізовано, з відомих, близько 49 поховань. Більша частина похованих зі зброєю дистанційного бою перебувала у склепах (85\%) - це близько чверті від всіх поховань зі зброєю $(26,2 \%)$.

На Усть-Альмінському некрополі знайдена ціла серія - 7 луків у 6-ти похованнях. У склепі 120/10 вдалося зафіксувати форму лука, який був з цільного дерева «подвійної кривизни з перехопленням у центрі», покладений праворуч біля ніг похованого. В інших випадках це прості луки, від яких збереглися дерев'яні деталі. Всі луки з Усть-Альмінського некрополя можна віднести до 1 типа («скіфського») за типології Н.Є. Берлізова ${ }^{30}$.

У похованнях Криму, як і на всій території проживання сарматської культури, наявність лука явище рідкісне. У мавзолеї Неаполя Скіфського в одному з поховань знаходилися залишки лука. Потім, у кам'яному склепі цього ж некрополя, було зо-

по археологии Дона. 2000. Ч. 1: Сарматы и их соседи на Дону. С. 174, Рис. 3.

22 Симоненко А.В. Сарматские всадники Северного Причерноморья... С. 57.

23 Кривошеев М.В. Вооружение позднесарматского времени нижнего Поволжья... С. 65.

24 Пуздровский А.Е. Крымская Скифия II в. до н.э. - III в. н.э. Погребальные памятники... С. 132.

25 Скрипкин А.С. Азиатская Сарматия. Саратов: Саратовский государственный университет, 1990.

C. 119; Пуздровский А.Е. Крымская Скифия II в. до н.э. - III в. н.э. Погребальные памятники... C. 137.

26 Труфанов А.А., Масякин В.В. Римский меч из Усть-Альминского некрополя (Юго-Западный Крым) // Stratum plus. 2019. Вып. 4. С. 133, 136, рис. 3-8.

27 Медведєв Г.В. Мечі та кинджали у поховальному обряді Усть-Альмінського некрополя... С. 267.

28 Ibid. Табл. 2,10; 4,14, 25;

29 Медведєв Г.В. Мечі та кинджали у поховальному обряді Усть-Альмінського некрополя... С. 276.

30 Пуздровский А.Е. Крымская Скифия II в. до н.э. - III в. н.э. Погребальные памятник... Рис. 90; Берлизов Н.Е. Ритмы сарматии. Савромато-сарматские племена Южной России в VII в. дон.э.V в. н. э. Ч. I. Краснодар: КГУКИ, Парабеллум, 2011. С. 84. 
браження лучника. На кам'яному рельєфі з Мар'їне (мікрорайон Сімферополя) вершник з вигнутим луком 31 . На надгробних стелах Боспору, де поховані представники сарматської знаті кінця I ст. до н.е. - першої половини II ст. н.е., разом з мечами були зображені луки «скіфського» та «гунського» типів 32.

У сарматських похованнях з другої половини I ст. н.е. з'являються луки 2 типу («гунського типу») з кістяними накладками та більшими наконечниками стріл до них. Це явище дослідники пов'язують з приходом кочівників «східної хвилі»33. На Усть-Альмінському некрополі залишків кістяних деталей луків не було виявлено, але великі наконечники були зафіксовані.

Поховання із сагайдачними наборами з Усть-Альмінського некрополя, склали майже половину від загальної кількості поховань у цілому зі зброєю дистанційного бою (46,9\%). Невеликі набори (по 4-17 стріл) знайдено у 12 похованнях (52,1\%). Великі набори (понад 20 стріл і до 146) були знайдені в 11 похованнях (47,9\%) переважно у похованнях військової еліти ${ }^{34}$. У похованнях даного некрополя, від сагайдаків збереглися лише деталі кріплень і прикрас.

У пізньоскіфських похованнях Криму перших століть н.е. великі сагайдачні набори зустрічалися нечасто. Такі набори, з невеликою кількістю стріл, знайдені у трьох похованнях мавзолею Неаполя Скіфського. В одному з поховань мавзолею сагайдак померлого виявився без стріл35. У некрополі біля с. Завітне, що у Південно-Західному Криму, в похованні I ст. н.е. перебував сагайдачний набір (51 наконечник) ${ }^{36}$.

У сарматів Нижнього Приуралля, Подоння та Нижнього Поволжя у ранньосарматський і середньосарматський час, у військових похованнях разом з мечами досить часто зустрічалися сагайдачні набори, здебільшого це були набори по 30-40 стріл ${ }^{37}$. Наприклад, у військових похованнях Чортовицького могильника, що на

\footnotetext{
31 Погребова Н.Н. Погребения в мавзолее Неаполя Скифского // Материалы института археологии. Вып. 96. Москва, 1961. С. 118; Дашевская О.Д. Поздние скифы в Крыму... С. 34, табл. 39, 5; 45, 4. 32 Горончаровский В.А. Между империей и варварами: военное дело Боспора римского времени. Санкт-Петербург-Москва, 2003. Рис. 24; Трейстер М.Ю. Оружие сарматского типа на Боспоре в III вв. н.э.... С. 486, Рис. 5, 2; 9.

33 Muscalu B. Arme sarmatice descoperite în mediul sarmatic dintre Tisa şi Dunăre // Bhaut - otebibliotheca historica et Arheologica universitatis Timisiensis. 2009. Vol. XI. S. 193; Симоненко А.В. Сарматские всадники Северного Причерноморья... С. 94; Зубов С.Э. Воинские миграции римского времени в Среднем Поволжье (I-III вв) // Миграционные процессы в формировании новой этнокультурной среды по материалам археологических данных. Saarbrücken, 2011. С. 43-44; Безуглов С.И. Степь и Танаис во II-III вв. н.э // Крым в сарматскую эпоху (II в. до н.э. - IV в. н.э.). Материалы $\mathrm{X}$ Международной научной конференции «Проблемы сарматской археологии и истории» / Отв. ред. И.Н. Храпунов. Вып. V. Симферополь, 2019. С. 49; Скрипкин А.С., Клепиков В.М. Археологические памятники II-I вв. до н.э. Нижнего Поволжья и некоторые этнические проблемы сарматов // Археологія і давня історія України. 2020. Вип. 3 (36). С. 219.

34 Медведєв Г.В. Мечі та кинджали у поховальному обряді Усть-Альмінського некрополя ... Табл. 5. 35 Погребова Н.Н. Погребения в мавзолее Неаполя Скифского... С. 118-120; 184, 188-190, рис. 10, I, IV; Дашевская О.Д. Поздние скифы в Крыму... С. 34.

36 Волошинов А.А., Масякин В.В. Погребения с оружием из некрополя римского времени у с. Заветное в Юго-Западном Крыму (раскопки 2005-2006 гг.) ... С. 292, Рис. 2; 4.

37 Косяненко В.М. Среднесарматское погребение из могильника Крепинский н левобережье реки Маныч // Сарматы и их соседи на Дону: Материалы и исследования по археологии Дона / Отв. ред. Ю.К. Гугуев. 2000. Вып. III. С. 90. Рис. 1; Мошкова М.Г. Среднесарматские и позднесарматские памятники на территории Южного Приуралья // Доклады к V Международной конференции «Проблемы сарматской археологии и истории». Сарматские культуры Евразии: проблемы региональной хронологии / Отв. ред. Б.А. Раев. Краснодар, 2004. С. 29; Глебов В.П. Погребальная обряд-
} 
Верхньому Дону, була велика кількість сагайдачних наборів. У наборах знаходилося по 30-60 стріл, а в інших некрополях зустрічалися поодинокі екземпляри ${ }^{38}$. На Підкумському могильнику з Центрального Передкавказзя в 39,4\% поховань у підбійних могилах I - початку II ст. н.е. перебувала значна кількість сагайдачних наборів ${ }^{39}$. У пізньосарматський час на Поволжі, наприклад, сагайдачні набори зустрічаються рідше і з меншою кількістю стріл 40.

Поховання з окремими наконечниками стріл в Усть-Альмінському некрополі по 1-3 стріли містилося в 24-х похованнях (48,9\%). Визначено, що на УстьАльмінському некрополі у 4-х випадках стріла могла бути причиною смерті і вони не враховані як ті, що містять стріли. На думку деяких дослідників, не всі поховання з одиничними наконечниками стріл можна вважати військовими. До військових, у нашому випадку, із загальної кількості поховань (24) можна віднести близько 8-9. А в інших похованнях стріли могли мати інший зміст у поховальному обряді, що міг відрізнятися від ролі військових.

За типологією А.Є. Пуздровського, або О.В. Симоненка, залізні черешкові наконечники з Усть-Альми відносяться до 4-х типів ${ }^{41}$. У Криму наконечники стріл перших століть нашої ери зустрічаються у похованнях пізніх скіфів, в основному поодиноко, або набори з невеликою кількістю стріл ${ }^{42}$.

ность раннесарматской культуры Нижнего Подонья во II-І вв. до н.э... С. 70; Глебов В.П., Толочко И.В. Женские погребения с оружием на Нижнем Дону в эпоху позднего эллинизма // Танаис и сарматы. Античная цивилизация и варварский мир Понто-Каспийского региона: Материалы Всероссийской научной конференции с международным участием (посвященной 70-летнему юбилею Б.А. Раева (Кагальник, 20-21 октября 2016 г.) / Отв. ред. С.И. Лукьяшко. Ростов-на-Дону, 2016. С. 46, Рис. 3; Яценко С.А. Группы элиты у сарматов // Элита в истории древних и средневековых народов Евразии / Отв. ред. П.К. Дашковский. Барнаул, 2015. С. 93-94; Медведев А.П., Березуцкий В.Д., Бирюков И.Е. Сарматы на Верхнем и Среднем Дону: результаты изучения и новые открытия // Крым в сарматскую эпоху (II в. до н.э. - IV в. н.э.). Материалы X Международной научной конференции «Проблемы сарматской археологии и истории». / Отв. ред. И.Н. Храпунов. Вып. V. Симферополь, 2019. С. 178; Скрипкин А.С. Сарматский погребальный комплекс II-I вв. до н.э из Заволжья // Нижневолжский археологический вестник. 2003. Вып. 6. С. 290, Рис. 1; 2, 1; Скрипкин А.С., Клепиков В.М. Археологические памятники II-I вв. до н.э. Нижнего Поволжья и некоторые этнические проблемы сарматов... С. 218, Рис. 1, 3, 5; 2.

38 Медведев А.П. Периодизация и хронология сарматских памятников на Среднем и Верхнем Дону. Доклады к V Международной конференции «Проблемы сарматской археологии и истории». Сарматские культуры Евразии: проблемы региональной хронологии / Отв. ред Б.А. Раев. Краснодар, 2004. С. 91.

39 Абрамова М.П. Подкумский могильник. Москва: Наука, 1987. С. 148.

40 Кривошеев М.В., Скрипкин А.С. Формирование и развитие позднесарматской культуры в Нижнем Поволжье (по данным погребального обряда) // Погребальный обряд ранних кочевников Евразии. Материалы и исследования по археологии Юга России. Сборник статей / Отв. ред. Г.Г. Матишов, Л.Т. Яблонский, С.И. Лукьяшко. Вып. ІІІ. Ростов-на-Дону, 2011. С. 152; Медведев А.П. Феномен Верхнедонских могильников в контексте позднесарматских и лесостепных культурных традиций // Погребальный обряд ранних кочевников Евразии. Материалы и исследования по археологии Юга России. Сборник статей / Отв. ред. Г.Г. Матишов, Л.Т. Яблонский, С.И. Лукьяшко. Вып. III. Ростов-на-Дону, 2011. С. 283, Рис. 3, 3; Новые сарматские курганы на Среднем Хопре // Археологія і давня історія України. 2020. Вип. 3 (36). С. 338, Рис. 5, 6; 6, 6.

41 Пуздровский А.Е. Крымская Скифия II в. до н.э. - III в. н.э. Погребальные памятники... С. 137-138; Симоненко А.В. Сарматские всадники Северного Причерноморья... С. 96-98.

42 Сымонович Э.А. Население столицы позднескифского царства (по материалам Восточного некрополя Неаполя скифского) ... С. 85, Табл. XVI, 8-10, 13-25; Богданова Н.А. Могильник первых веков нашей эры у с. Заветное... С. 59; Пуздровский А.Е. Погребения Битакского могильника первых веков н.э. с оружием и конской уздой... Рис. 7, 5; Puzdrovskij A.E. Tomb of Early Roman Period from 
У пізньоскіфських похованнях, та на інших сарматських територіях, переважно зустрічалися наконечники стріл 1 (2) типу. Наприклад, у військовій могилі з некрополя біля с. Опушки були знайдені три наконечника черешкових стріл, два з них 1 (2) типу і одна 3 (1) типу43. У могильнику Бельбек IV серед зброї наконечники стріл практично були відсутні, за винятком архаїчних ${ }^{44}$.

В якості порівняння, більшість (49) чоловічих поховань «Золотого кладовища» що з Прикубання, були військовими, й у наборах серед іншої зброї в 14 випадках були стріли, і тільки у 4-х похованнях - тільки одні стріли 45.

У пізньосарматський час на Нижньому Поволжі у військових похованнях наконечники стріл стають рідкісним явищем, у 4\% з 19\% поховань зі зброєю, переважно це одиничні екземпляри ${ }^{46}$.

Положення дистанційної зброї (луків і стріл) у похованні. Основне положення наборів стріл (колчанів) зліва біля ніг (стоп, гомілки, стегна) наконечниками вниз, поодинокі винятки $з$ цього правила: випадок коли стріла біля черепу (с. 520/2a), інший (м. 848) біля плеча, у склепах 120/10 і 620/2 - справа біля ніг. Поодинокі наконечники стріл перебували на кістяку (грудях, животі).

Луки знаходились у склепах 120/10, 520/34 справа біля ніг, у чотирьох похованнях (склепи 550/3, 4, 14) - зліва (рис. 3, III), 590/12 - біля ніг і плеча та в області пояса. А набори стріл містилися з луками тільки у склепі 120/10, а в склепі 520/34 - одна стріла між кісток ніг, у склепі 590/12 - на животі похованого перебували держаки стріл без наконечників ${ }^{47}$.

Поховання зі зброєю дистанційного бою датують аналогічно мечам і кинджалам. Починаючи з другої половини II ст. н.е. поховання з такою зброєю на УстьАльмінському некрополі, як і на сарматських територіях, зустрічаються все рідше.

У поховальному обряді Усть-Альмінського некрополя зброя дистанційного бою має важливу роль після клинкової зброї $(26,9 \%)$, як і у кочових сарматів.

Наконечники списів знайдені у 25 похованнях Усть-Альмінського некрополя, це 15,1\% від загальної кількості поховань зі зброєю, або 13,3\% від загальної кількості одиниць зброї (11 - у склепах і 14 - у могилах). Наконечники списів з УстьАльмінського некрополя А.Є. Пуздровський поділяє на 3 типи і два наконечники відносить до дротиків ${ }^{48}$. А.А. Труфанов за типологією О.В. Симоненка поділив їх на 4 типи ${ }^{49}$. Більшість наконечників датуються в межах другої половини I - першої половини II ст. н.е. 50

the Region of Scythian Neapolis //Ancien Civilizations from Scythia Siberia. 2005. Vol. 11. S. 92, Fig. 7, 35; 9, 15-17; Зайцев Ю.П., Мордвинцева В.И. Подвязные фибулы в варварских погребениях Северного Причерноморья позднеэллинистического периода // Российская археология. 2003. Вып. 2. С. 149; Дашевская О.Д. Некрополь Беляуса... С. 87.

43 Храпунов И.Н. Погребение воина 2 в. н.э. из могильника Опушки... С. 116, Рис. 2, 3-5.

44 Гущина И.И., Журавлев Д.В. Некрополь римского времени Бельбек IV в Юго-Западном Крыму... C. 73-74.

45 Гущина И.И., Засецкая И.П. «Золотое кладбище» римской эпохи в Прикубанье. Санкт-Петербург: Фарн, 1994. С. 37-38, Прилож. 4.

46 Кривошеев М.В. Вооружение позднесарматского времени нижнего Поволжья... С. 69.

47 Медведев Г.В. Оружие дистанционного боя... табл. 1.

48 Пуздровский А.Е. Крымская Скифия II в. до н.э. - III в. н.э. Погребальные памятники... С. 133.

49 Труфанов А.А. Наконечники копий из Усть-Альминского некрополя... С. 58-59; Симоненко А.В. Сарматские всадники Северного Причерноморья... С. 70-74.

50 Труфанов А.А. Наконечники копий из У сть-Альминского некрополя... С. 59. 
У Криму в невеликій кількості наконечники списів знайдені у Східному некрополі Неаполя Скіфського, Беляуса, Бітака51.

У поховальному обряді сарматів спис на основних територіях не мав широкого використання52. Але були і винятки - поховання із Середнього Заволжя, вони складають приблизно 2/3 від усіх «військових» у «Пісеральско-Андріївських» курганах $^{53}$. А так само Верхнедонскі поховання піздньосарматского часу, зі значною кількістю наконечників списів ${ }^{54}$. У Прикубанні на «Золотому кладовищі» відомо 15 наконечників списів 55 . Або, наприклад, у сарматських похованнях Альфельда, списи на відміну від мечів, частіше використовувалися у поховальній практиці 56 .

У кількісному відношенні, поховання 3 наконечниками списів 3 УстьАльмінського некрополя також виділяються серед інших некрополів пізньоскіфської культури Криму. Широке поширення наконечників списів у поховальному обряді могильника, за часом відбувається аналогічно часу поширенню мечів і кинджалів та зброї дистанційного бою.

У похованні наконечник списа розташований, у більшості випадків, біля ніг праворуч або ліворуч, далі біля черепа або плеча, і в окремих випадках біля тазу. В усіх похованнях з наконечниками списів, він був єдиною зброєю, за винятком двох поховань (м. 737 і 848), в яких знаходився меч (кинджал) і набір стріл (рис. 5) 57.

Залізні сокири виявлені у похованнях Усть-Альмінського некрополя у кількості трьох екземплярів. Вони перебували у могилах № 132 - (ПдС) друга половина II ст. н.е., № 63 - (ПдПд3) середина III в. н.е., й у № 741 - (ПдС) першої половини III cт. н.е. ${ }^{58}$ Сокири у похованнях були розташовані праворуч біля стегна (таза) (рис. 4, III, IV).

У сарматських похованнях залізні сокири серед зброї зустрічаються досить рідко, і дослідники висловлювали сумнів в їх тільки бойовому призначенні ${ }^{59}$. Проте, у некрополі Неаполя Скіфського й у мавзолеї, у різні роки досліджень, були знайдені три сокири ${ }^{60}$. Так само у Південно-Західному Криму були знайдені три сокири. Од-

\footnotetext{
51 Сымонович Е.А. Население столицы позднескифского царства... табл. XV, Дашевская О.Д. Поздние скифы в Крыму... табл. 60, 16-25; Пуздровский 2007, рис. 89, 5.

52 Симоненко А.В. Сарматские всадники Северного Причерноморья... С. 70; Храпунов И.Н., Эстер И., Кульчар В., Стоянова А.А. Оружие сарматского времени... С. 8.

53 Зубов С.Э. Воинские миграции римского времени в Среднем Поволжье (I-III вв) // Миграционные процессы в формировании новой этнокультурной среды по материалам археологических данных... С. 103.

54 Медведев А.П., Березуцкий В.Д., Бирюков И.Е. Сарматы на Верхнем и Среднем Дону: результаты изучения и новые открытия... С. 182.

55 Гущина И.И., Засецкая И.П. «Золотое кладбище» римской эпохи в Прикубанье... С. 9.

56 Храпунов И.Н., Эстер И., Кульчар В., Стоянова А.А.: Оружие сарматского времени... С. 11.

57 Труфанов А.А. Наконечники копий из Усть-Альминского некрополя... С. 59; Медведєв Г.В. Мечі та кинджали у поховальному обряді Усть-Альмінського некрополя... Табл. 4, 24, 35.

58 Пуздровский А.Е. Крымская Скифия II в. до н.э. - III в. н.э. Погребальные памятники... С. 134.

59 Хазанов А.М. Очерки военного дела сарматов... С. 51; Копылов В.П., Коваленко А.Н. 0 формировании элитарной культуры у племен среднесарматского времен // Античная цивилизация и варварский мир Понто-Каспийского региона. Материалы всероссийской научной конференции с международным участием, (посвященной 70-летнему юбилею Б.А. Раева. Кагальник, 2021 октября 2016 г.) / Отв. ред. С.И. Лукьяшко. Ростов-на-Дону: ЮНЦ РАН, 2016. С. 128-129; Пуздровский А.Е. Крымская Скифия II в. до н.э. - III в. н.э. Погребальные памятники... С. 134.

60 Сымонович Э.А. Население столицы позднескифского царства... Рис. 5, 30; Дашевская О.Д. Поздние скифы в Крыму... С. 35, Табл. 60, 27-28; Шульц П.Н. Мавзолей Неаполя Скифского. Москва: Наука, 1953. Табл. XI, 3; Погребова Н.Н. Погребения в мавзолее Неаполя Скифского // Материалы института археологии. 1961. Вып. 96. С. 120, Рис. 11, 5; С. 134, Рис. 89, 1.
} 
на з них походить з дореволюційних розкопок кургану 3 біля с. Долинне, два інших - $з$ могильника Мангуш 61. У Бітакському могильнику в підбійній могилі № 29/1 знаходилася залізна сокира 62 . Решта сокир, знайдених у Криму, відносяться, переважно, до пізньоримського часу63.

Часто сокири зустрічаються саме у комплекті з іншою зброєю в елітних похованнях. Наприклад, у кургані біля с. Олонешти (Молдова) у наборі серед зброї знаходилася сокира64. У Прикубанні в «Золотому Кладовищі» дві сокири включені авторами до таблиці як зброю65 (хоча в окремих випадках в обряді сокира могла мати іншу роль). Наприклад, у похованні № 1 кургану могильника Височина V (Нижній Дон), у жіночих похованнях пізньосарматського часу серед інвентарю перебували сокири 66. Можливо, у таких похованнях сокира, як, наприклад, і меч, могли нести роль соціального індикатора, особливо у жіночих похованнях.

На Усть-Альмінському некрополі зі 171 поховання зі зброєю, велика частина зброї містилася у склепах (80,7\%). У 36 могилах зі зброєю, більше половини з них $(60,1 \%)$ перебувало у підбійних могилах, інші - у грунтових могилах із заплечиками.

Орієнтація визначена у 101 (59,0\%) похованні зі зброєю, і була переважно у південному секторі (45,5\% від визначених), з них з відхиленнями до ПдС $(67,3 \%)$ і до Пд3 (34,7\%). У північному секторі виявлено 23,7\% від визначених поховань, 3 них 3 відхиленнями до Пн3 (62,5\%) і до ПнС (29,1\%). У 41\% поховань зі зброєю орієнтація не визначена через пограбування.

В якості аналогії слід зазначити, що для степового населення середньосарматського часу, наприклад, у середньому Поволжі або Південному Приураллі переважає південний сектор орієнтувань з відхиленнями на схід $(11,8 \%)$, або захід $(26,7 \%)^{67}$. Для поховань I - початку II ст. н.е. збільшуються Пд і ПдЗ орієнтування при загальному зменшенні всіх інших68. На Середньому і Верхньому Дону у середньосарматський час більшість чоловічих поховань (30-40 років) були орієнтовані, в основному, у південному півколі. Але у пізньосарматський час, ситуація у цих районах також змінюється убік зменшення кількості поховань зі зброєю й орієнтація зміщується у північний сектор ${ }^{69}$. Воронезька група сарматських поховань виділя-

\footnotetext{
61 Кулаковский Ю.А. Отчет о раскопках в Таврической губернии в1895 г. // Научный архив Института истории материальной культуры РАН. Ф.1. Дело АК. 1895. № 90. С. 18, Рис. 35; Высотская Т.Н. Усть-Альминское городище и некрополь... С. 150, Рис. 24, 5.

62 Пуздровский А.Е. Крымская Скифия II в. до н.э. - III в. н.э. Погребальные памятники... С. 134, Рис. 89, 2.

63 Храпунов И.Н., Эстер И., Кульчар В., Стоянова А.А. Оружие сарматского времени в Крыму... С. 9.

${ }^{64}$ Курчатов С.И., Бубулич В.Г. Сарматское погребение из кургана у с. Олонешты... С. 290, Рис. 3.

65 Гущина И.И., Засецкая И.П. «Золотое кладбище» римской эпохи в Прикубанье... Прил. 4, Табл. 10, 97; 468, 467.

66 Безпалый Е.И. Позднесарматское погребение из могильника Высочино V на водоразделе между Кагальником и Доном // Сарматы и их соседи на Дону: Материалы и исследования по археологии Дона. 2000. Вып. І. С. 159, Рис. 1; 3, 3; Мошкова М.Г. Два позднесарматских погребения в группе «Четыре брата» на Нижнем Дону // Вопросы древней и средневековой археологии Восточной Европы / Отв. ред. В.И. Козенкова, Ю.А. Каснов, И.Г. Розенфельтд. Москва: Наука, 1978. С. 73, Рис. 2, 3.

67 Мошкова М.Г. Среднесарматские и позднесарматские памятники на территории Южного Приуралья //. Доклады к V Международной конференции «Проблемы сарматской археологии и истории». Сарматские культуры Евразии: проблемы региональной хронологии / Отв. ред Б.А. Раев. Краснодар, 2004. С. 23.

${ }_{68}$ Скрипкин А.С. Азиатская Сарматия... С. 184.

${ }^{69}$ Медведев А.П., Березуцкий В.Д., Бирюков И.Е. Сарматы на Верхнем и Среднем Дону... С. 177-178, 182.
} 
ється значною кількістю військових поховань (Чертовицькі могильники I, II) $(37,2 \%)$ чоловічі поховання зі зброєю переважає ПдС орієнтація70. Аналогічна ситуація простежується у цей час в Нижньому Поволжі - зброя простежена тільки у $21,3 \%$ поховань ${ }^{71}$.

Поза у похованих на Усть-Альмінському некрополі, в основному витягнута на спині (у 101-му випадку визначена), руки вздовж тулуба. Присутні випадки схрещених ніг у померлих (9 випадків), в окремих випадках одна або обидві ноги зігнуті (ромбом), іноді рука на тазі (животі). В одному випадку в склепі 777/2 було зафіксовано нестандартне положення кістяка: «кістки рук покладені на середню частину тулуба або заведені за спину. Кістки таза неприродно вивернуті, ноги схрещені в колінах, при цьому тазостегнові суглоби також неприродно вивернуті». Імовірно воїн був розчленований під час бою, а під час поховання його поклали по частинам не в анатомічному порядку, можливо випадково, а можливо що з певною метою72. У сарматів відомі випадки поховань у нестандартних позах ${ }^{73}$.

Дерев'яні труни виявлені у 37 похованих, з них 10 поховань перебували в колодах, у п'яти випадках поховані були розташовані, ймовірно, на настилах (склеп 777), в одному випадку простежується тлін, мабуть від савана (кошми?) (М. 848). У семи похованих знайдена м'ясна їжа - кістка частіше у головах, могла бути в тарілці з ножем. В окремих випадках у похованнях перебували вудила і деталі кінського спорядження, в основному в елітних похованнях ${ }^{74}$.

Після середини I в. н.е. відбуваються зміни в етнічній і соціальній структурі Усть-Альмінського городища. До середини I ст. н.е. зброя на некрополі досить рідкісне явище. Починаючи з другої половини I ст. н.е. Усть-Альмінський некрополь різко виділяється за кількістю поховань зі зброєю, серед некрополів пізньоскіфської культури Криму. На Усть-Альмінському городищі відбувається різке збільшення кількості населення, можливо за рахунок переселення сюди сарматівнайманців (військових дружин) з території Боспору. У цей час на некрополі виділяється поховання військової еліти. Починаючи з середини - другої половини II ст. н.е. кількість військових поховань на Усть-Альмінському некрополі скорочується.

Елементи поховального обряду некрополя знаходять аналогії у традиціях сарматської культури кочового й осілого населення Північного Причорномор'я, Поволжя, Подоння та Боспору.

Зміни у поховальному обряді Усть-Альмінського некрополя пов'язані з воєннополітичними подіями, які відбувались у Криму. У І ст. н.е. Херсонес і велика частина Криму і території пізньоскіфської держави перебували під контролем Боспор-

\footnotetext{
70 Медведев А.П.. Этнокультурные процессы на верхнем Дону в сарматское время (II в. до н.э. III в. н.э.) // Вестник Воронежского государственного университета: История, политология, социология. 2006. Вып. І. С. 41; Медведев А.П., Березуцкий В.Д., Бирюков И.Е. Сарматы на Верхнем и Среднем Дону... С. 181.

${ }^{71}$ Кривошеев М.В. Вооружение позднесарматского времени нижнего Поволжья... С. 65.

72 Пуздровский А.Е. Склеп с элитными воинскими погребениями из Усть-Альминского некрополя... С. 188; Пуздровский А.Е., Труфанов А.А. Полевые исследования Усть-Альминского некрополя в 2000-2003 гг... С. 43.

73 Балабанова М.А. Поза погребенных как объект археолого-этнографических исследований (по погребальным комплексам позднесарматского времени) // Погребальный обряд ранних кочевников Евразии. Материалы и исследования по археологии Юга России. Сборник статей / Отв. ред. Г.Г. Матишов, Л.Т. Яблонский, С.И. Лукьяшко. Вып. ІІІ. Ростов-на-Дону, 2011. С. 32.

74 Медведєв Г.В. Мечі та кинджали у поховальному обряді Усть-Альмінського некрополя... Табл. 5.
} 
ського царства. Кримська Скіфія брала участь у римсько-боспорських війнах 4549 pр. н.е. на стороні Боспору, в усякому разі на перших етапах. Варвари у 62 р. н.е. осаджують Херсонес, а для усунення загрози захоплення міста, намісник Риму Нижньої Мезії Плавтій Сільван організував військову експедицію. У ІІ ст. н.е. відбуваються військові дії Боспорської армії на території Кримської Скіфії ${ }^{5}$, що не могло не відбитися у змінах поховального обряду.

\section{REFERENSCES}

Abramova, M.P. (1987). Podkumskii mogilnik [Podkum burial ground]. Moskva: Nauka [in Russian].

Babenchikov, V.P. (1949). Novyi uchastok nekropolia Neapolia Skifskogo [New sector of the necropolis Naples Scythian]. Vestnik drevnei istorii, 1, 111-119 [in Russian].

Balabanova, M.A. (2011). Poza pogrebennykh kak obiekt arkheologo-etnograficheskikh issledovanii (po pogrebalnym kompleksam pozdnesarmatskogo vremeni) [Pose of the Buried as an Object of Archaeological and Ethnographic Research (Based on Burial Complexes of the Late Sarmatian Time)]. In Matishov, G.G., Yablonskii, L.T. \& Lukiahko, S.I. (Eds.). Pogrebalnyi obriad rannikh kochevnikov Evrazii. Materialy i issledovaniia po arkheologii Yuga Rossii (Vol. III, pp. 23-39). Rostov-na-Donu [in Russian].

Bezpalyi, E.I. (2000). Pozdnesarmatskoe pogrebenie iz mogilnika Vysochino V na vodorazdele mezhdu Kagalnikom i Donom [Late Sarmatian burial from the VysochinoV burial ground at the watershed between Kagalnik and Don]. Sarmaty i ix sosedi na Donu: Materialy i issledovaniia po arkheologii Dona (Vol. I, pp. 156-158) [in Russian].

Bezuglov, S.I. (2000). Pozdnesarmatskie mechi (po materialam Podonia) [Late Sarmatian swords (by materials of the Don)]. Materialy i issledovaniia po arkheologii Dona, Sarmaty i ikh sosedi na Donu, (Vol. 1, pp. 169-193). Rostov-na-Donu [in Russian].

Bezuglov, S.I. (2019). Step i Tanais vo II-III vv. n.e [The Steppe and Tanais in the Second and Third Centuries AD]. Krym v sarmatskuiu epokhu (II v. do n.e. - IV v. n.e.). Materialy X Mezdunarodnoi nauchnoi konferentsii «Problemy sarmatskoi arkheologii i istorii», (Vol. V, pp. 47-52). Simferopol [in Russian].

Bezuglov, S.I. \& Glebov, V.P. (2014). Rannesarmatskoe pogrebenie s dvumia mechami iz mogilnika Sukho-Duderevskii II [Early Sarmatian burial with two swords from the burial ground SukhoDiuderevskiy II]. Voina i voennoe delo v skifo-sarmatskom mire. Materialy mezhdynarodnoi naychnoi konferentsii pamiati A.I. Meliukovoi, (pp. 49-56). Rostov-na-Donu: UNTS RAN [in Russian].

Berlizov, N.E. (2011). Ritmy sarmatii. Savromato-sarmatskie plemena Yuzhnoi Rossii v VII v. don.e. $V$ v. n.e. [Rhythms of Sarmatia. Savromato -Sarmatian tribes of southern Russia in the VII Century BC - V Century AD]. Vol. I, Krasnodar: KGUKI, Parabellum [in Russian].

Bogdanova, N.A. (1989). Mogilnik pervykh vekov nashei ery u s. Zavetnoie [Burial ground of the first centuries $\mathrm{AD}$ near the village of Zavetnoie]. Arkheologicheskie issledovaniia na Yuge Vostochnoi Evropy. Trudy Gosudarstvennogo muzeia (Vol. 70, pp. 18-70). Moskva [in Russian].

Bogdanova, N.A., Gushchina, I.I. \& Loboda, I.I. (1974). Mogilnik Skalistoe III v Yugo-Zapadnom Krymu (I-III vv. n.e.) [Burial ground Skalistoye III in the South-West Crimea (I-III centuries AD)]. Sovetskaia arkheologiia, 4, 121-152 [in Russian].

Dashevskaia, O.D. (1991). Pozdnie skify v Krymy. Svod arkheologicheskikh istochnikov [Late Scythians in Crimea (Code of Archaeological Sources)]. Vol. D 1-7. Moskva: Nauka [in Russian].

Goroncharovskii, V.A. (2003). Mezhdu imperiei i varvarami: voennoe delo Bospora rimskogo vremeni [Between the Empire and the barbarians: the military affairs of the Bosporus during the Roman period]. Sankt-Petersburg - Moskva [in Russian].

Glebov, V.P. (2011). Pogrebalnaia obriadnost rannesarmatskoi kultury Nizhnego Podonia III vv. do n.e. [Funeral rituals of the Early Sarmatian culture of the Lower Don region of the $3^{\text {rd }}$ century BC]. In

75 Щеглов Н. Северо-Западный Крым в античную эпоху. Ленинград: Наука, 1978. С. 135; Колтухов С.Г. Укрепление Крымской Скифии. Симферополь: Сонат, 1999. С. 97; Пуздровский А.Е. Политическая история Крымской Скифии во II в. до н.э. - III в. н.э // Вестник древней истории. 2001. Вып. 3. С. 109; Пуздровский А.Е. Крымская Скифия II в. до н.э. - III в. н.э. Погребальные памятники... С. 89; Уженцев В.Б. Эллины и варвары Прекрасной Гавани (Калос Лимен в IV в. до н.э. - II в. н.э.). Симферополь, Универсум, 2006. С. 135; Медведев Г.В. Три погребения первых веков нашей эры с мечами из Усть-Альминского некрополя... С. 104. 
Matishov, G.G.. Yablonskii, L.T. \& Lukiashko, S.I. (Eds.). Pogrebalnyi obriad rannikh kochevnikov Evrazii. Materialy i issledovaniia po arkheologii Yuga Rossii. Sbornik statei, (Vol. III, pp. 63-87). Rostov-na-Donu [in Russian].

Glebov, V.P. \& Parusimov, I.N. (2000). Novye sarmatskie pogrebeniia v baseine r. Sal (o sootnoshenii rannesarmatskoi i srednesarmatskoi kultur) [New Sarmatian burials in the river basin Sal (on the ratio of early Sarmatian and Middle Sarmatian cultures]. In Guguev, Yu.K. (Ed.). Sarmaty i ikh sosedi na Donu: Materialy $i$ issledovaniia po arkheologii Dona, (Vol. III, pp.61-89). Rostov-na-Donu [in Russian].

Glebov, V.P. \& Tolochko, I.V. (2016). Zhenskie pogrebeniia s oruzhiem na Nizhnem Donu v epokhu pozdnego ellinizma: Tanais i sarmaty [Female burials with weapons in the Lower Don in the era of late Hellenism: Tanais and Sarmatians]. In Lukiashko, S.I. (Ed.). Antichnaia tsivilizatsiia $i$ varvarskii mir Ponto-Kaspiiskogo regiona: materialy Vserossiiskoi nauchnoi konferentsii s mezhdunarodnym uchastiem, (pp. 44-84). Rostov-na-Donu [in Russian].

Gushchina, I.I. (1967). O sarmatakh v Yugo-Zapadnom Krymu [About the Sarmatians in the South-West Crimea]. Sovetskaia arkheologiia, 1, 40-51 [in Russian].

Gushchina, I.I. \& Zasetskaia, I.P. (1994). «Zolotoe kladbishche» rimskoi epokhi v Prikubanie [«Golden cemetery» of the Roman age in the Kuban' basine]. Sankt-Petersburg [in Russian].

Gushchina, I.I. \& Zhuravliov, D.V. (2016) Nekropol rimskogo vremeni Belbek IV v Yugo-Zapadnom Krymu [Necropolis of the Roman Period Belbek IV in Southwestern Crimea]. Trudy Gosudarstvennogo Istoricheskogo Muzeia, (Vol. 205, T. 1). Moskva [in Russian].

Gushchina, I.I. \& Zhuravliov, D.V. (2016). Nekropol rimskogo vremeni Belbek IV v Yugo-Zapadnom Krymu [Necropolis of the Roman Period Belbek IV in Southwestern Crimea]. Trudy Gosudarstvennogo Istoricheskogo Muzeia (Vol. 205, T. 2). Moskva [in Russian].

Khazanov, A.M. (1971). Ocherki voennogo dela sarmatov [Essays on the military affairs of the Sarmatians]. Moskva: Nauka [in Russian].

Khrapunov, I.N. (2007). Pogrebenie voina 2 v. n.e. iz mogilnika Opushki [Burial warrior of 2nd century $\mathrm{AD}$ from the Opushki burial ground]. In Zaitsev, Yu.P. \& Mordvintseva, V.I. (Eds.). Drevniaia Tavrika. Simferopol: Universum, (pp. 115-124) [in Russian].

Khrapunov, I.N. (2010). Oruzhie iz mogilnika Neizats [Weapons from the Neizats burial ground]. Terra Barbarica. Monumenta archeological Barbarica. Series Gemina II, 535-556 [in Russian].

Khrapunov, I.N., Masiakin, V.V. \& Muld, S.A. (1997). Pozdneskifskii mogilnik u s. Kolchugino [Late Scythian burial ground near the village Kolchugino]. Bakhchisaraiskii istoriko-kulturnyi sbornik, 1, 76155 [in Russian].

Khrapunov, I.N., Ester, I., Kulchar, V. \& Stoianova, A.A. (2020). Oruzhie sarmatskogo vremeni v Krymu i v Alfelde [Weapons of the Sarmatian time in the Crimea and in Alfeld]. Materialy po arkheologii, istorii i etnografii Tavrii, XXV, 5-24 [in Russian].

Koltukhov, S.G. (1999). Ukrepleniia Krymskoi Skifii [Fortifications of the Crimean Scythia]. Simferopol: Sonat [in Russian].

Kopylov, V.P. \& Kovalenko, A.N. (2016). O formirovanii elitarnoi kultury u plemen srednesarmatskogo vremeni [On the formation of an elite culture among the tribes of the Middle Sarmatian time]. In Lukiashko, S.I. (Ed.). Antichnaia tsivilizatsiia $i$ varvarskii mir Ponto-Kaspiiskogo regiona. Materialy vserossiiskoi nauchnoi konferentsii (Kagalnik, 20-21 oktiabria, 2016), (pp. 125-129). Rostov-na-Donu [in Russian].

Kosianenko, V.M. (2000). Srednesarmatskoe pogrebenie iz mogilnika Krepinskii I na levoberezhie reki Manych [Middle Sarmatian burial from the Krepinsky burial ground on the left bank of the Manych River]. In Guguev, Yu.K. (Ed.). Sarmaty i ikh sosedi na Donu: Materialy i issledovaniia po arkheologii Dona, (Vol. III, pp. 90-94) [in Russian].

Krivosheev, M.V. (2007). Vooruzhenie pozdnesarmatskogo vremeni nizhnego Povolzhia [Armament of the late Sarmatian time Lower Volga region]. In Yablonskiy, L.T. \& Tairov, A.D. (Eds.) Doklady $k$ VI mezhdunarodnoi konferentsii «Problemy sarmatskoi arkheologii $i$ istorii». Vooruzhenie sarmatov: regionalnaia tipologiia i khronologiia, (pp. 65-70). Cheliabinsk [in Russian].

Krivosheev, M.V. \& Skripkin, A.S. (2011). Formirovanie i razvitie pozdnesarmatskoi kultury v Nizhnem Povolzhie (po dannym pogrebalnogo obriada) [Formation and development of the late Sarmatian culture in the Lower Volga region (according to the burial rite)]. In Matishov, G.G., Yablonskii, L.T. \& Lukyashko, S.I. (Eds.) Pogrebalnyi obriad rannikh kochevnikov Evrazii. Materialy i issledovaniia po arkheologii Yuga Rossii. (Vol. III, pp. 146-164). Rostov-na-Donu [in Russian].

Kulakovskii, Yu.A. (1895). Otchet o raskopkakh $v$ Tavricheskoi gubernii v $1895 \mathrm{~g}$. [Report on excavations in the Tauride province in 1895]. NA IIMK RAN (F. 1, Delo AK, Vol. 90) [in Russian]. 
Kurchatov, S.I. \& Bubulich, V.G. (2003). Sarmatskoe pogrebenie iz kurgana u s. Oloneshty - 40 let spustia [Sarmatian burial from a mound near the village Oloneshty - 40 years later]. In Sava, E. (Ed.). Vzaimodeistvie kultur i khronologiia Severo-Pontiiskogo regiona, (pp. 285-312). Kishinev [in Russian].

Limberis, N.Yu. \& Marchenko, I.I. (2012). Pogrebenie sarmatskogo voina na nekropole meotskogo gorodishcha [Burial of a Sarmatian warrior at the necropolis of the Meotian settlement]. Evraziia $v$ skifo-sarmatskoe vremia. Trudy gosudarstvennogo istoricheskogo muzeia, 191, 261-281 [in Russian].

Marchenko, I.I. (1996). Siraki Kubani [Siraki of Kuban]. Krasnodar: KGU [in Russian].

Medvedev, A.P. (2004). Periodizatsiia i khronologiia sarmatskikh pamiatnikov na Srednem i Verkhnem Donu [Periodization and chronology of Sarmatian monuments in the Middle and Upper Don]. In Raiev, B.A. (Ed.). Doklady $k$ V Mezhdunarodnoi konferentsii «Problemy sarmatskoi arkheologii $i$ istorii». Sarmatskie kultury Evrazii: problemy regionalnoi khronologii, (pp. 86-94). Krasnodar [in Russian].

Medvedev, A.P. (2006). Etnokulturnye protsessy na Verkhnem Donu v sarmatskoe vremia (II v. do n.e. III v. n.e.) [Ethnocultural processes in the Upper Don in the Sarmatian Time (II century BC III century AD)]. Vesnik Volgogradskogo gosudarstvennogo universiteta. Seriia: istoriia, politologiia, sotsiologiia, 1, 33-45 [in Russian].

Medvedev, A.P. (2011). Fenomen Verkhnedonskikh mogilnikov v kontekste pozdnesarmatskikh i lesostepnykh kulturnykh traditsii [The phenomenon of the Upper Don burial grounds in the context of the Late Sarmatian and forest-steppe cultural traditions]. In Matishov, G.G. Yablonskiy, L.T. \& Lukiashko, S.I. (Eds.). Pogrebalnyi obriad rannikh kochevnikov Evrazii. Materialy i issledovaniia po arkheologii Yuga Rossii, (Vol. III, pp. 277-293). Rostov-na-Donu [in Russian].

Medvedev, A.P. (2020). Novye sarmatskie kurgany na Srednem Khopre [New Sarmatian burial mounds in the Middle Khoper]. Arheologiia i davnia istoriia Ukrainy, 3, 334-346 [in Russian].

Medvedev, A.P., Berezutskii, V.D. \& Biriukov, I.E. (2019). Sarmaty na Verkhnem i Srednem Donu: rezultaty izucheniia i novye otkrytiia [The Sarmatians in the Upper and Middle Don Areas: The Results of Researches and New Discoveries]. In Khrapunov, I.N. (Ed.). Krym v sarmatskuiu epokhu (II v. do n.e. - IV v. n.e.). Materialy X Mezhdunarodnoi nauchnoi konferentsii «Problemy sarmatskoi arkheologii i istorii», (pp. 175-187). Simferopol [in Russian].

Medvedev, G.V. (2010). Mogily s «kollektivnymi» pogrebeniiami iz Ust-Alminskogo nekropolia [Graves with «collective» burials from Ust'-Al'ma necropolis]. Arheologicheskii almanakh, 22, 219-234 [in Russian].

Medvedev, G.V. (2019). Tri pogrebeniia pervykh vekov nashei ery s mechami iz Ust-Alminskogo nekropolia [Three burials of the first centuries of our era with swords from the Ust'-Al'ma]. Istoriia $i$ arkheologiia Kryma, IX, 100-113 [in Russian].

Medvedev, G.V. (2020). Mechi ta kindzhaly u pokhovalnomu obriadi Ust-Alminskogo nekropolia [Swords and daggers in the funeral ritual of the Ust'-Al'ma necropolis]. Arkheologiia i davnia istoriia Ukrainy, 3 (36), 266-280 [in Ukrainian].

Mordvintseva, V.N. (2016). Decorated swords as emblems of power on the steppes of the northern Black Sea region (3rd century BC. - $3^{\text {rd }}$ century AD). Anabasis. Studia Classica et Orientalia, 6 (2015), 174-215.

Moshkova, M.G. (1978). Dva pozdnesarmatskikh pogrebeniia v gruppe «Chetyre brata» na Nizhnem Donu [Two late Sarmatian burials in the «Four Brothers» group in the Lower Don]. Voprosy drevnei $i$ srednevekovoi arkheologii Vostochnoi Evropy, (pp. 71-77). Moskva: Nauka [in Russian].

Moshkova, M.G. (2004). Srednesarmatskie i pozdnesarmatskie pamiatniki na territorii Yuzhnogo Priuralia [Middle Sarmatian and Late Sarmatian sites in the Southern Urals]. In Raiev, B.A. (Ed.). Doklady k V Mezhdunarodnoi konferentsii «Problemy sarmatskoi arkheologii i istorii». Sarmatskie kultury Evrazii: problemy regionalnoi khronologii, (pp. 22-44). Krasnodar [in Russian].

Muscalu, B. (2009). Arme sarmatice descoperite în mediul sarmatic dintre Tisa şi Dunăre. Bhaut otebibliotheca historica et Arheologica universitatis Timisiensis, XI, 191-208.

Pogrebova, N.N. (1961). Pogrebeniia v mavzolee Neapolia Skifskogo [Burials in the mausoleum of Scythian Naples]. Materialy instituta arkheologii, 96, 103-213 [in Russian].

Puzdrovskii, A.E. (2001). Pogrebeniia Bitakskogo mogilnika pervykh vekov n. e. s oruzhiem i konskoi uzdoi [Burials of the Bitak burial ground of the first centuries AD with weapons and horse bridle]. Pozdnie skify Kryma. Trudy Gosudarstvennogo istorikheskogo muzeia, 118, 122-140 [in Russian].

Puzdrovskii, A.E. (2001). Politicheskaia istoriia Krymskoi Skifii vo II v. do n.e. - III v. n.e. [The political history of Crimean Scythia in the II century BC - III century AD]. Vestnik drevnei istorii, 3, 86-118 [in Russian].

Puzdrovskii, A.E. (2005). Tomb of Early Roman Period from the Region of Scythian Neapolis. Ancien 
Civilizations from Scythia Siberia 11, 1-2, 85-105.

Puzdrovskii, A.E. (2007). Krymskaia Sktfiia. II v. do n.e. - III v. n.e. Pogrebalnye pamyatniki [Crimean Scythia. $2^{\text {nd }}$ century BC $-3^{\text {rd }}$ century AD Burial monuments]. Simferopol: Biznes-Inform [in Russian].

Puzdrovskii, A.E. (2015). Sklep s elitnymi voinskimi pogrebeniiami iz Ust-Alminskogo nekropolia [Crypt with elite military burials from the Ust-Alma necropolis]. Istoriia i arkheologiia Kryma, I, 186199 [in Russian].

Puzdrovskij, A.E. \& Zajcev, J.P. (2004). Prunkbestattungen des I Jh. n. c. in der Nekropole Ust-Al'ma auf der Krim. Die Ausgrabungen des Jahres 1999. Eurasia antiqua, 10, 229-267.

Puzdrovskii, A.E. \& Medvedev, G.V. (2005). Pogrebeniia I-II vv. n.e. iz Ust-Alminskogo nekropolia [Burials of the 1-2nd centuries AD from the Ust-Alma necropolis]. Khersonesskii sbornik, XIV, 271-282 [in Russian].

Puzdrovskii, A.E. \& Trufanov, A.A. (2016). Pogrebenie vonina iz Ust-Alminskogo nekropolia (mogila 848) [A warrior-grave from Ust-Al'ma necropolis (grave 848)]. Istoriia i arkheologiia Kryma, IV, 27 37 [in Russian].

Puzdrovskii, A.E. \& Trufanov, A.A. (2016). Polevye issledovaniia Ust-Alminskogo nekropolia v 2008$2014 \mathrm{gg}$. [Field studies of the Ust'-Al'ma Necropolis in 2008-2014] (Ust-Alminskoe gorodishche i nekropol v Yugo-Zapadnom Krymu, 1). Simferopol-Moscow: Brovko A.A. [in Russian].

Puzdrovskii, A.E. \& Trufanov, A.A. (2017). Polevye issledovaniia Ust-Alminskogo nekropolia v 2008$2014 \mathrm{gg}$. [Field studies of the Ust'-Al'ma Necropolis in 2004-2007] (Ust-Alminskoe gorodishche i nekropol v Yugo-Zapadnom Krymu, 2). Simferopol-Moscow: Brovko A.A. [in Russian].

Puzdrovskii, A.E. \& Trufanov, A.A. (2017b). Polevye issledovaniia Ust-Alminskogo nekropolia v 2000$2003 \mathrm{gg}$. [Field studies of the Ust'-Al'ma Necropolis in 2008-2014] (Ust-Alminskoe gorodishche i nekropol v Yugo-Zapadnom Krymu, 3). Simferopol-Moscow: Brovko A.A. [in Russian].

Sadowski, S. (2004). Miecz z grobu 8 cmientarzyska Zvenihorod - «Hoeva Hora» na Ukraine. Przyczynek do badań nad rozprzestrzenieniem się mieczy z pierścieniowatym zakończeniem rękojeści. Sarmaci $i$ germanie. Lublin Uniwersytetu Marii Curie-Skłodowskiej, 265-288.

Sadovski, S. (2006). Mechi i kinzhaly s koltsevym navershiem [Swords and daggers annular finial]. In Zinko, V.N. (Ed.). Bosporskie chteniia. Bospor Kimeriiskii $i$ varvarskii mir $v$ period antichnosti $i$ srednevekovia. Oikoc. Kerch, pp. 254-255 [in Russian].

Simonenko, A.V. (2010). Sarmatskie vsadniki Severnogo Prichernomoria [Sarmatian riders of North Pontic region]. Sankt-Petersburg: Sankt-Peterburgskiy gosudarstvennyiy universitet [in Russian].

Simonenko, A.V. (2014). Periodizatsiia voennogo dela nomadov Evrazii v epokhu rannego zheleza [The periodization of the military affairs of the nomads of Eurasia in the era of the early iron]. In Lukiashko, S.I. (Ed.). Voina $i$ voennoe delo $v$ skifo-sarmatskom mire. Materialy mezhdunarodnoi nauchnoi konferentsii pamiati A.I. Meliukovoi. Rostov-na-Donu, pp. 329-344 [in Russian].

Skripkin, A.S. (1990). Aziatskaia Sarmatiia [Asian sarmatia]. Saratov: SGU [in Russian].

Skripkin, A.S. (2003). Sarmatskiy pogrebalnyi kompleks II-I vv. do n. e iz Zavolzhia [The Sarmatian funeral complex of the II-I century B.C. from the territory of steppe Zavolzhye]. Nizhnevolzhskii arkheologicheskii vestnik, 6, 289-29 [in Russian].

Skripkin, A.S. (2014). Klinkovoe oruzhie v razrabotke khronologii i nekotorykh voprosov etnopoliticheskoi istorii rannesarmatskoi kultury Volgo-Uralskogo regiona [Blade weapons in the development of chronology and some issues of the ethnopolitical history of the early Sarmatian culture of the Volga-Ural region]. In Lukiashko, S.I. (Ed.). Voina i voennoe delo v skifo-sarmatskom mire. Materialy mezhdunarodnoi nauchnoi konferentsii pamiati A.I. Meliukovoi, (pp. 367-379). Rostovna-Donu [in Russian].

Skripkin, A.S. \& Klepikov, V.M. (2020). Arkheologicheskie pamiatniki II-I vv. do n.e. Nizhnego Povolzhia i nekotorye etnicheskie problemy sarmatov [Archaeological Sites of the Lower Volga Region of the $2^{\text {nd }}-1^{\text {st }}$ centuries BC and some Ethnic Issues of the Sarmatians]. Arheologiia i davnia istoriia Ukrainy, 3 (36), 214-222 [in Russian].

Symonovich, E.A. (1983). Naselenie stolitcy pozdneskifskogo tsarstva (po materialam Vostochnogo nekropolia Neapolia Skifskogo) [Population of the capital of the late Scythian kingdom (according to materials from the Eastern Necropolis of Scythian Naples)]. Kiev: Naukova dumka [in Russian].

Treister, M.Yu. (2010). Oruzhie sarmatskogo tipa na Bospore v I-II vv. n.e. [On the weapons of Sarmatian type in the Bosporan Kingdom in the $1^{\text {st }}-2^{\text {nd }}$ centuries AD]. Drevnosti Bospora, 14, 484561 [in Russian].

Trufanov, A.A. (2016). Nakonechniki kopii iz Ust-Alminskogo nekropolia [Spear-heads from the Ust'Al'ma necropolis]. Istoriia i arkheologiia Kryma, IV, 47-61 [in Russian].

Trufanov, A.A. \& Mordvintseva, V.I. (2016). Voinskoe pogrebenie serediny I v. n.e. iz Ust-Alminskogo 
nekropolia (Yugo-Zapadnyi Krym) [A warrior grave of the 1st century AD from the Ust'-Al'maa ntcropolis (The South -Wtestern Crimea)]. Problemy istorii, filologii, kultury, 2, 196-212 [in Russian].

Trufanov, A.A. \& Masiakin, V.V. (2019). Rimskii mech iz Ust-Alminskogo nekropolia (Yugo-Zapadnyi Krym) [Roman Sword from Ust'-Alma Necropolis (South-Western Crimea)]. Stratum plus, 4, 133-145 [in Russian].

Uzhentsev, V.B. (2006). Elliny i varvary Prekrastnoi Gavani (Kalos Limen v IVv. do n.e. - II v. n.e.) [Hellenes and barbarians of the Beautiful Harbor (Kalos-Limen in the $4^{\text {th }}$ century BC $-2^{\text {nd }}$ century AD)]. Simferpol: Universum [in Russian].

Shults, P.N. (1953). Mavzolei Neapolia Skifskogo [Mausoleum of Naples Scythian]. Moskva: Nauka [in Russian].

Shcheglov, A.N. (1978). Severo-Zapadnyi Krym v antichnuiu epokhu [Northwestern Crimea in the Ancient Era]. Leningrad: Nauka [in Russian].

Voloshinov, A.A. \& Masiakin, V.V. (2007). Pogrebeniia s oruzhiem iz nekropolia rimskogo vremeni u s. Zavetnoe v Yugo-Zapadnom Krymu (raskopki 2005-2006 gg.) [Burials with weapons from the necropolis of the Roman period near the village of Zavetnoe in the Southwestern Crimea (excavations 2005-2006)]. In Zaitsev, Yu.P. \& Mordvintseva, V.I. (Eds.). Drevniaia Tavrika, (pp. 291-302). Simferopol: Universum [in Russian].

Vysotskaia, T.N. (1994). Ust-Alminskoe gorodishche i nekropol [Ust-Alminskoe Settlement and Necropolis]. Kiev: Kievskaia Akademiia Evrobiznesa [in Russian].

Yatsenko, S.A. (2015). Gruppy elity u sarmatov [Elite groups of Sarmatians]. In Dashkovskii, P.K. (Ed.). Elita v istorii drevnikh i srednevekovykh narodov Evrazii. Barnaul, pp. 86-98 [in Russian].

Zaitsev, U.P. \& Mordvinttseva, V.I. (2003). Podviaznye fibuly v varvarskikh pogrebeniiakh Severnogo Prichernomoria pozdneellinisticheskogo perioda [The Fibulae With Bindings in the Barbarian Burials of North Pontic Area in the Late Hellenic Period]. Rossiiskaia arkheologiia, 2, 134-154 [in Russian].

Zubov, S.E. (2011). Voinskie migratsii rimskogo vremeni v Srednem Povolzhe (I-III vv.). Migratsionnye protsessy $v$ formirovanii novoi etnokulturnoi sredy po materialam arkheologicheskikh dannykh [Military migrations of the Roman period in the Middle Volga region (I-III century AD). Migration processes in the formation of a new ethnocultural environment based on archaeological data]. Saarbrücken [in Russian].

\section{Gennadii Medvedev}

(Institute of Archeology of Crimea, Simferopol, Autonomous Republic of Crimea) e-mail: medvedgen@gmail.com

ORCID: https://orcid.org/0000-0003-0977-8321

\section{Weapons in Obsequial Rite of Ust-Alminsk Necropolis (South-Western Crimea)}

In terms of the number of weapons, Ust-Alminsk necropolis stands out among the late Scythian sites of the Crimea. The burials with weapons, considering their typology, chronology, statistics, as well as the place and role in the rite are studied in the paper. Primary role of weapons in the obsequial rite is their functional purpose. The analysis of burial complexes showed that a significant number of bladed weapons were in the first place, while at the second place in the obsequial rite of Ust-Alminsk necropolis were remote weapons (bows and arrows), the third took spears, and the last - axes.

From the middle of the first century CE, the number of weapons increased in the burial complexes of Ust-Alminsk necropolis. At that time, Chersonese and much of the Crimea (including the state of the late Scythians) were under the control of the Bosporan Kingdom. Crimean Scythia participated in the Bosporan-Roman War as an ally of Bosporus. In the second century CE, the hostilities of Bosporan army took place in the Crimean Scythia. Those events were reflected in the obsequial rite.

In the first centuries of CE in Ust-Alminsk necropolis appeared the traditions of an obsequial rite, peculiar to the population of the Sarmatian era of steppe areas of the Northern Black Sea region and Volga region. This can be observed in the peculiarities of the obsequial rite. In addition, there were changes in the ethnic and social structure of late Scythian society, 
since along with the civilian, the military elite was formed. That was reflected in the richness of the obsequial inventory of military burials.

Keywords: late Scythian culture, burial with weapons, Sarmatians, swords and daggers, remote weapons, spears, axes

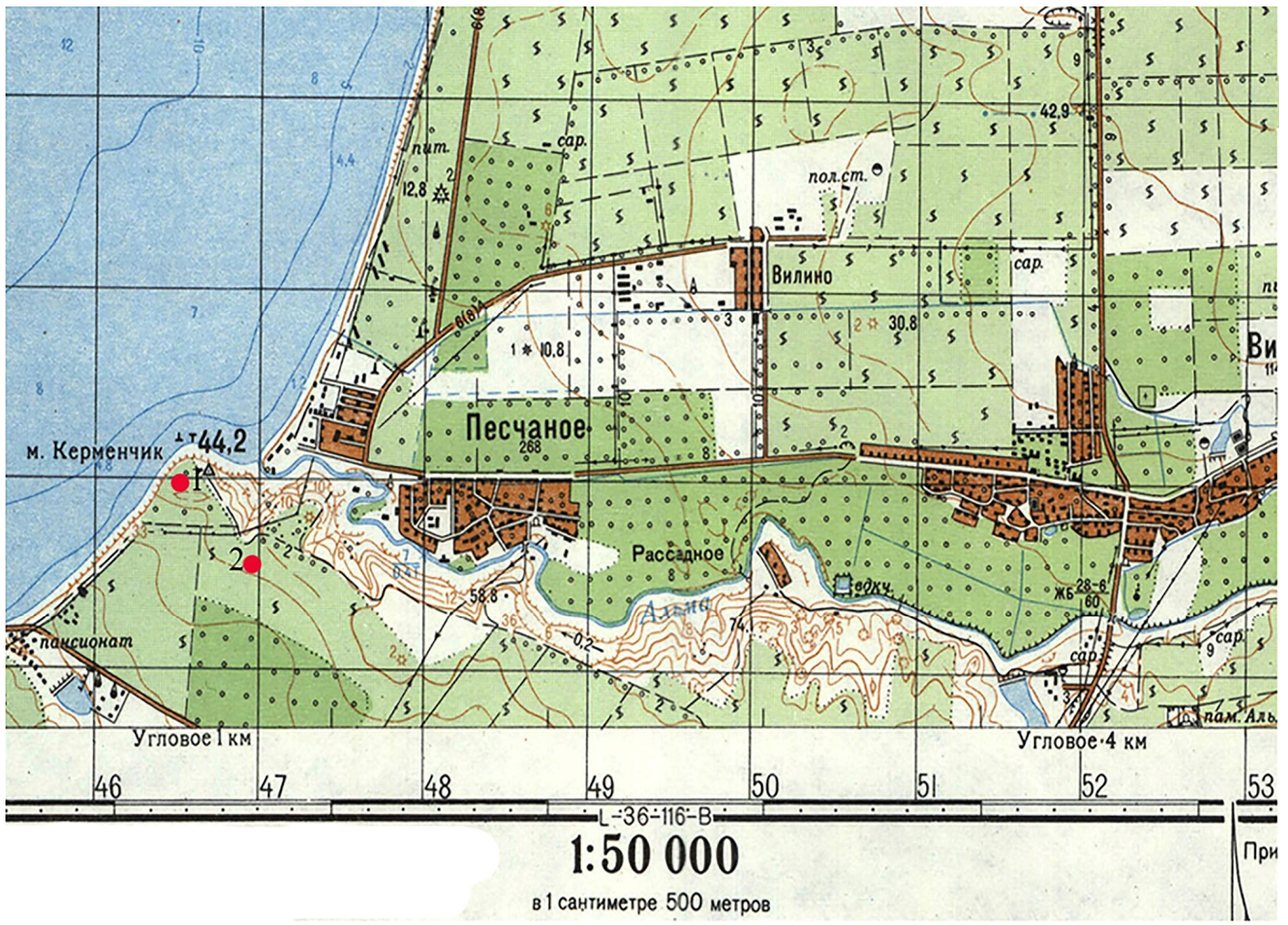

Рис. 1. Географічне положення Усть-Альмінського городища і некрополя (Бахчисарайський район, Автономна Республіка Крим) 1 - Усть-Альмінське городище, 2 - Усть-Альмінський некрополь 


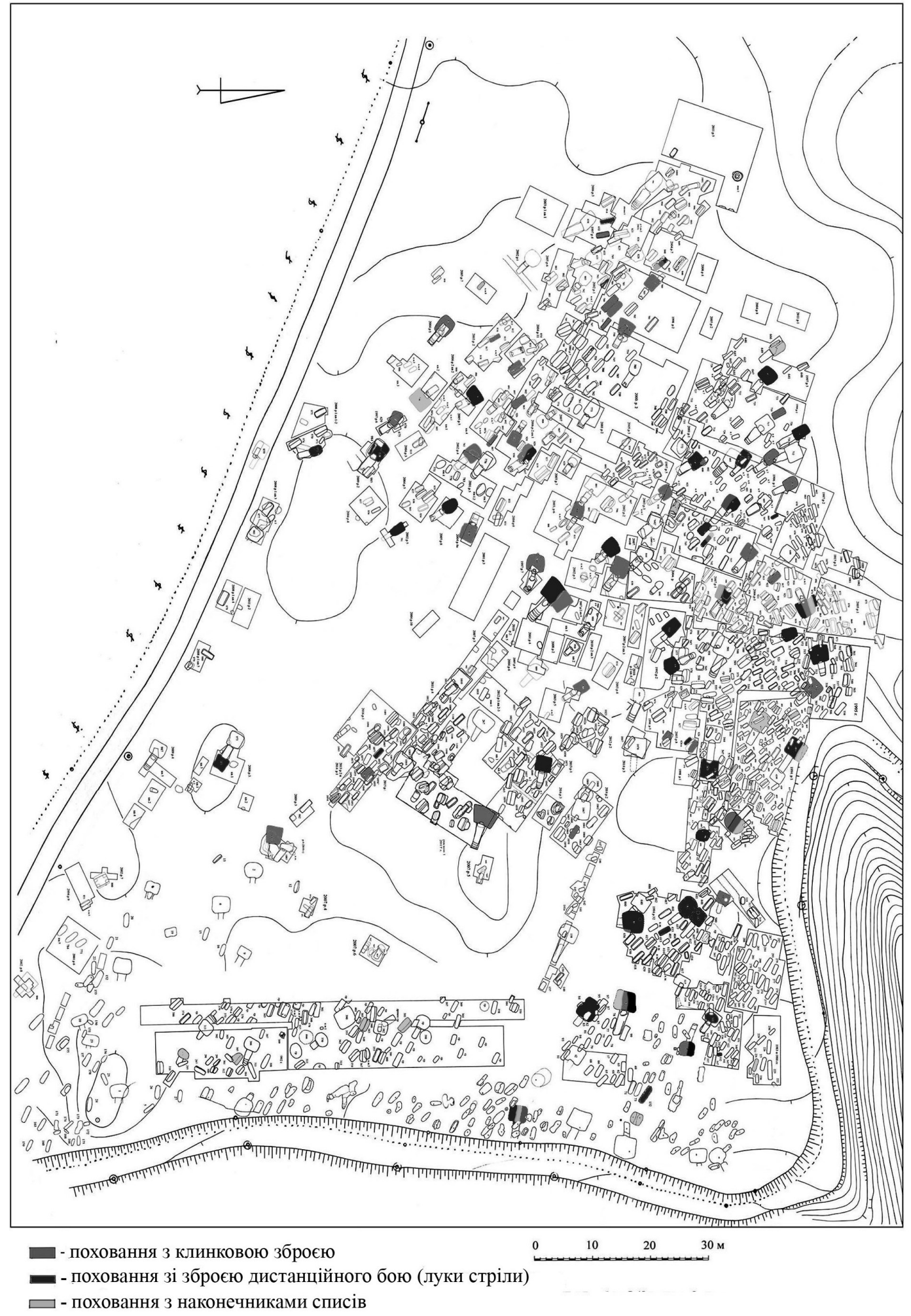

Рис. 2. План Усть-Альмінського некрополя з похованнями зі зброєю. 

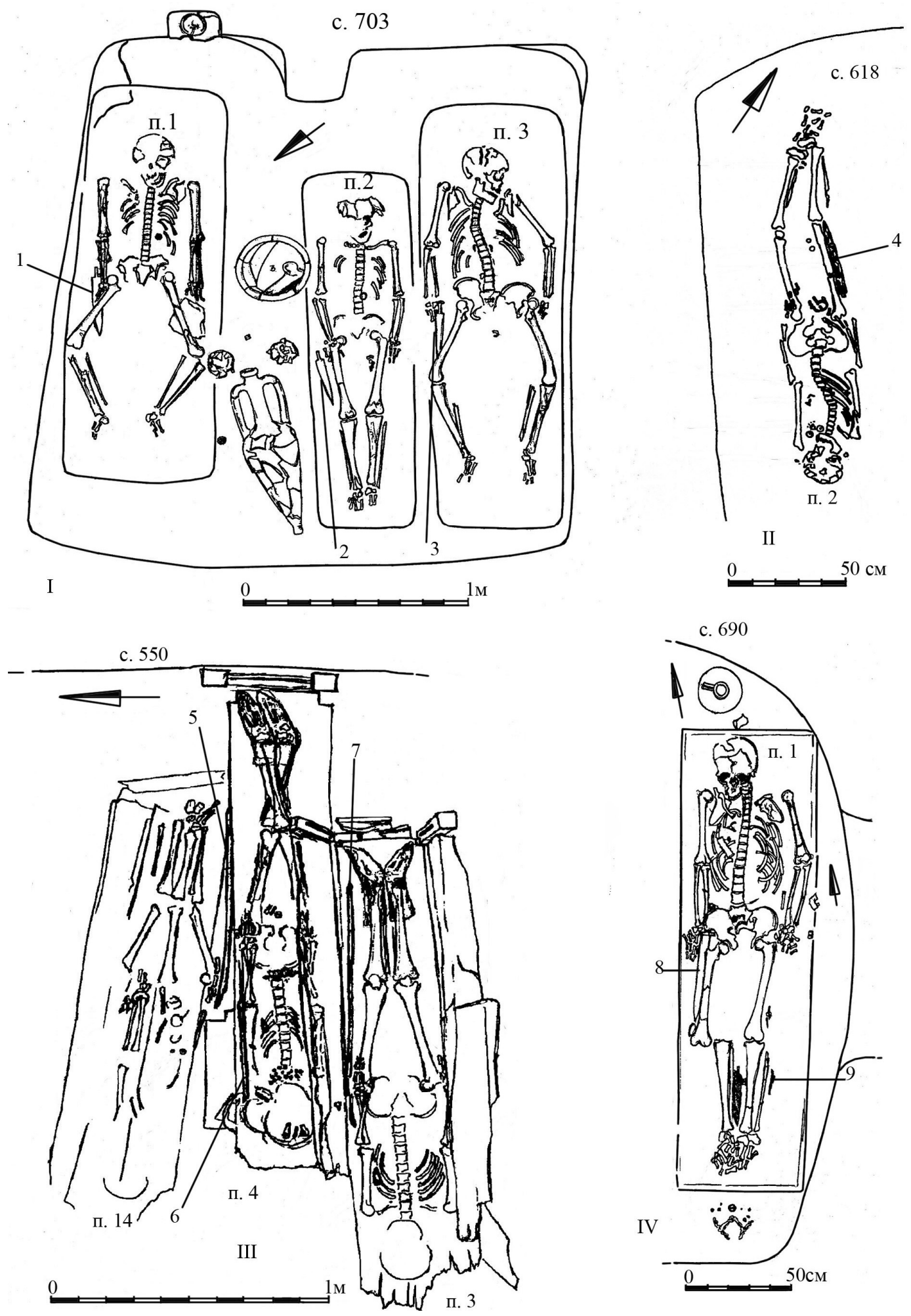

Рис. 3. Поховання зі зброєю із склепів Усть-Альмінського некрополя: I - с. 703: 1-3 - кинджали; II - с. 618/2: 4 - меч; III - с. 550/3, 4, 14: 5-7 - луки; IV - с. 690/1: 8 - меч, 9 - стріли. 

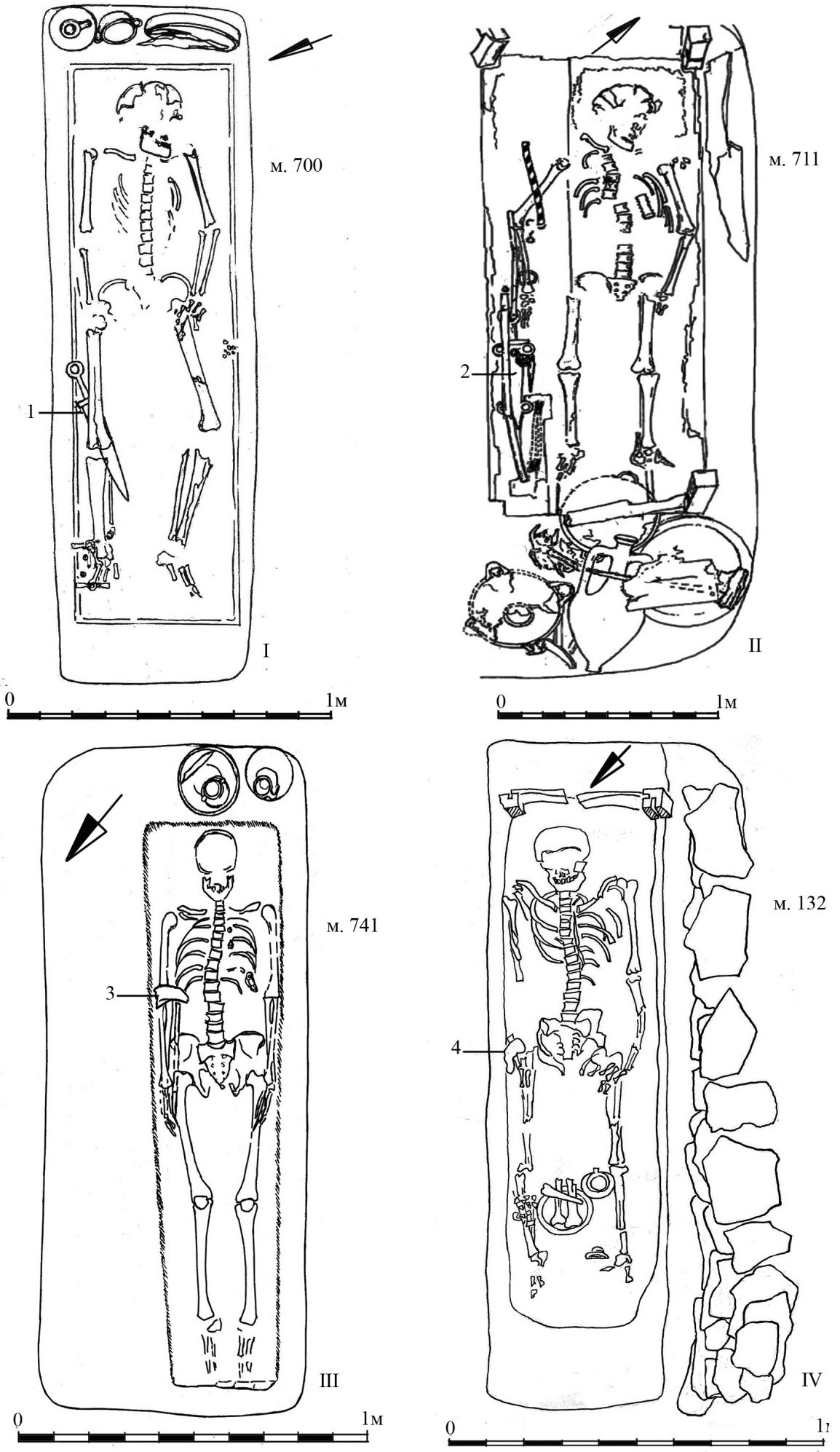

Рис. 4. Могили зі зброєю з Усть-Альмінського некрополя: I, II - м. 700, 711: 1, 2 - мечі, III, IV - м. 741, 132: 3, 4 - сокири. 

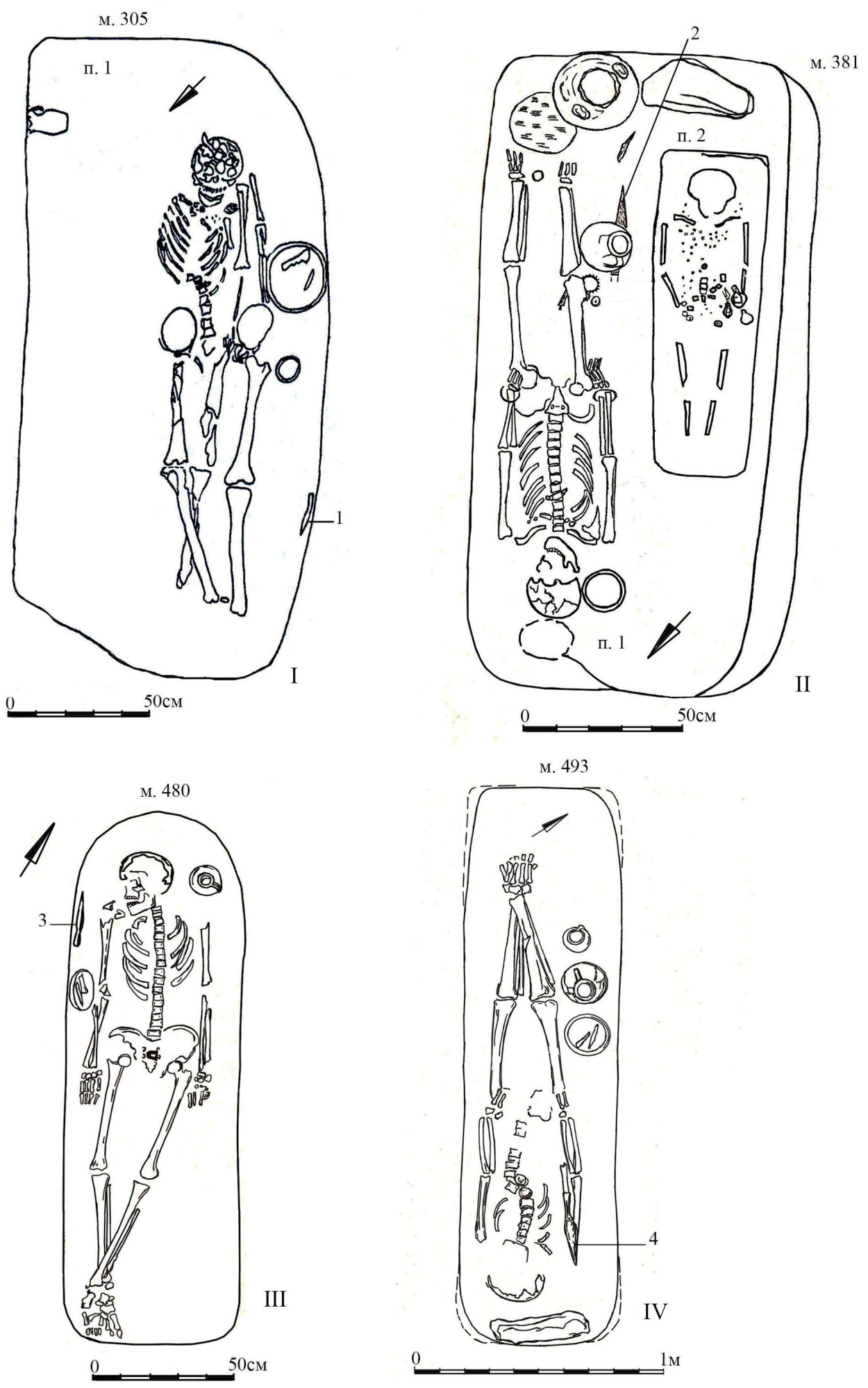

Рис. 5. Могили зі зброєю з Усть-Альмінського некрополя: I-IV - м. 305, 381, 480, 493: 1-4 - наконечники списів. 